\title{
Caterpillar hair in the eye
}

\author{
Reena Singh, Koushik Tripathy, Rohan Chawla, Sudarshan Khokhar
}

Department of Ophthalmology, Dr Rajendra Prasad Centre for Ophthalmic Sciences, AllMS, New Delhi, India

\section{Correspondence to} Dr Rohan Chawla, dr.rohanrpc@gmail.com

Accepted 16 February 2017

\section{DESCRIPTION}

A 12-year-old boy presented with a 5-day history of foreign body sensation, redness, pain and photophobia in the left eye (LE). The patient gave a history of playing in fields 5 days before his symptoms. He had used topical antibiotics and artificial tears without relief. At presentation, the visual acuity was $20 / 20$ in both eyes. On slit-lamp examination, linear fine foreign bodies (caterpillar-hair) were seen buried in the superficial and deep corneal stroma. The ends of some hair were seen penetrating through the cornea into the anterior chamber (AC) (figure 1, arrow). There were 2+ cells and 1+ flare in the AC, and cells in the vitreous of LE. The left optic disc and macula were normal. Preretinal small vitreous exudates were noted in LE (figure 2, arrow). On anterior segment optical coherence tomography of the cornea, intrastromal hair could be documented (figure 3, arrow). The patient was started on topical treatment with prednisolone six times per day, homatropine four times a day and moxifloxacin three times a day. After 2 weeks of therapy, the AC and retrolental cells decreased. Surprisingly, corneal hair decreased in number but the number of posterior segment lesions increased. This may be due to the migration of hair from the AC to posterior segment, which is known to occur with caterpillar hair. ${ }^{1}$ Caterpillar hair (setae) are sharp and fine with unidirectional barbs due to which they can migrate towards the base. $^{2}$ Oral steroids were also added from fear of aggravation of posterior segment inflammation.

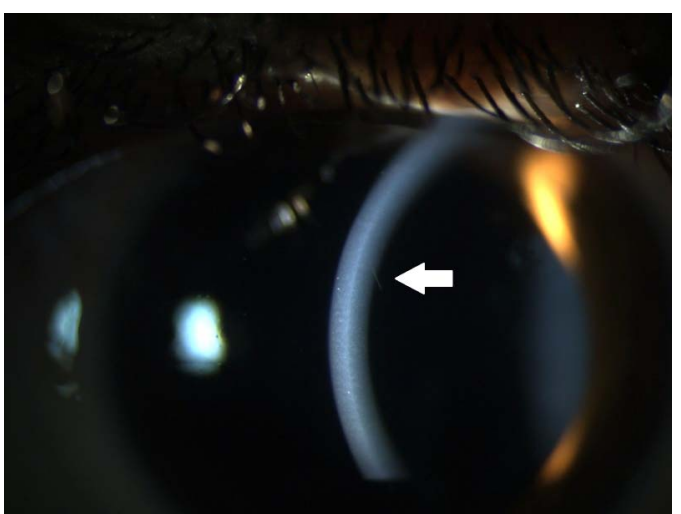

To cite: Singh $\mathrm{R}_{,}$Tripathy $\mathrm{K}_{\text {, }}$ Chawla $\mathrm{R}$, et al. BMJ Case Rep Published online: [please include Day Month Year] doi:10.1136/bcr-2017219392
CrossMark

Figure 1 Slit-lamp photograph shows a deep intracorneal seta (arrow) protruding inside the anterior chamber.

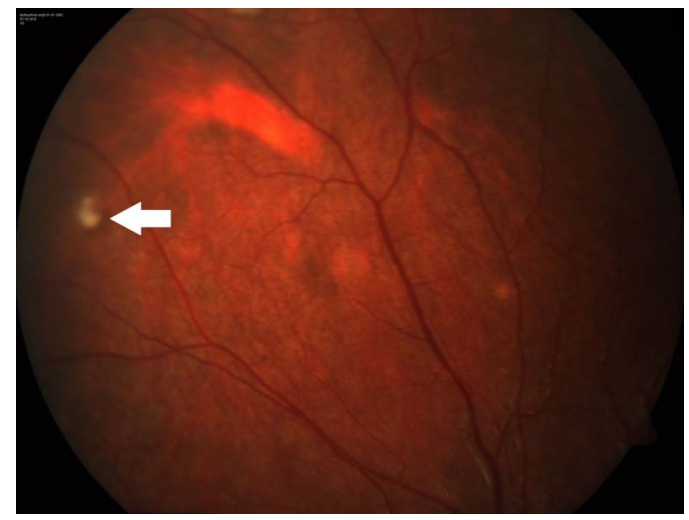

Figure 2 The posterior segment showed preretinal small vitreous infiltrates (arrow).

Following this, the vitreous exudates reduced. The topical and oral steroids were slowly tapered. However, even after 2 months of treatment, the patient is not totally free of inflammation, thought the visible hair have drastically reduced in number. We plan to maintain him on a low dose of steroids until the inflammation totally subsides.

The diagnosis of caterpillar-hair was clinical in our case, as we could not retrieve any foreign body and could not confirm these with a microscope. However, the pattern of anterior segment inflammation and increased involvement of posterior segment with reduction in corneal foreign bodies at follow-up gave us clinical clues to the diagnosis. In many cases, direct history of exposure to caterpillar hair may not be available. ${ }^{3}$ Upper lid eversion to search for retained setae is mandatory and any conjunctival or iris nodules should be removed. Intraocular penetration of setae causes severe anterior segment reaction. However, the anterior segment inflammation usually responds to topical steroids and cycloplegic. Vitritis may require intravitreal or systemic steroids and some eyes of ophthalmia nodosa may develop phthisis. ${ }^{1}$ In our case, removal of hair was not possible as all the hair were buried. We did not plan any invasive surgery, as patient's initial response to treatment with topical steroids was good and no vision-threatening complications arose. There are reports of intraocular setae without subsequent reactivation. ${ }^{4}$ Such cases should be followed closely as late migration and late worsening has also been reported in some of these cases. ${ }^{5}$ 
Figure 3 The anterior segment optical coherence tomography revealed a hair (arrow) in the anterior corneal stroma.

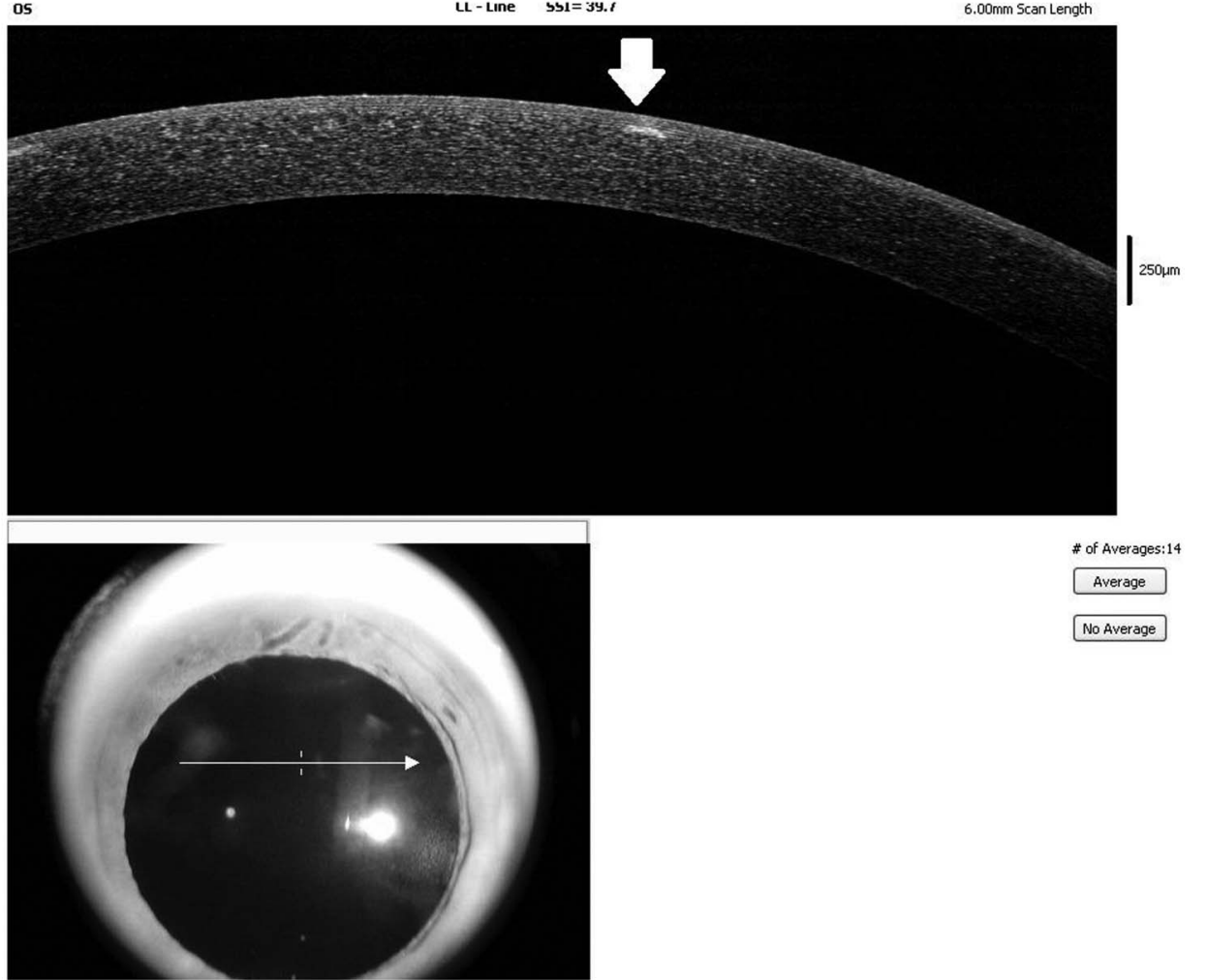

Competing interests None declared.

Patient consent Obtained.

Provenance and peer review Not commissioned; externally peer reviewed.

\section{REFERENCES}

1 Sengupta S, Reddy PR, Gyatsho J, et al. Risk factors for intraocular penetration of caterpillar hair in Ophthalmia Nodosa: a retrospective analysis. Indian J Ophthalmo 2010;58:540-3.

2 Watson PG, Sevel D. Ophthalmia nodosa. Br J Ophthalmol 1966:50:209-17.

3 Bishop JW, Morton MR. Caterpillar-hair keratoconjunctivitis. Am J Ophthalmol 1967;64:778-9.

4 Ibarra MS, Orlin SE, Saran BR, et al. Intraocular caterpillar setae without subsequent vitritis or iridocyclitis. Am J Ophthalmol 2002;134:118-20.

Contributors RS collected the patient data. RS and KT prepared the initial drafts. $\mathrm{RS}, \mathrm{RC}$ and SK were involved in the management of the patient. All authors were involved in interpretation of the data and critical revision of intellectual contents.
5 Bhende M, Biswas J, Sharma T, et al. Ultrasound biomicroscopy in the diagnosis and management of pars planitis caused by caterpillar hairs. Am J Ophthalmol 2000;130:125-6

Copyright 2017 BMJ Publishing Group. All rights reserved. For permission to reuse any of this content visit http://group.bmj.com/group/rights-licensing/permissions.

BMJ Case Report Fellows may re-use this article for personal use and teaching without any further permission.

Become a Fellow of BMJ Case Reports today and you can:

- Submit as many cases as you like

- Enjoy fast sympathetic peer review and rapid publication of accepted articles

- Access all the published articles

- Re-use any of the published material for personal use and teaching without further permission

For information on Institutional Fellowships contact consortiasales@bmjgroup.com

Visit casereports.bmj.com for more articles like this and to become a Fellow 